\title{
Het aantrekken van kapitaal door de uitgifte van obligaties door een MKB-onderneming*
}

\author{
J.M. Brussen \& I.P.M.J. Janssen
}

\section{Inleiding}

Wanneer MKB-ondernemingen (te) weinig eigen middelen hebben, hebben zij daardoor behoefte aan externe financiering. ${ }^{1}$ Een MKB-onderneming die twintig jaar geleden een financiering nodig had, ging naar de bank voor een bancaire lening of krediet. Wanneer zij vandaag de dag een financiering nodig heeft, zijn er legio mogelijkheden. Een MKB-onderneming kan nog altijd bij de bank aankloppen. Maar zij kan haar financiering onder andere ook ophalen via een crowdfundingplatform, factoring, MKB-krediet, 'business angels', kredietunies, een participatiefonds of een (MKB-)beurs. ${ }^{2}$ Deze alternatieve financieringsvormen zijn sterk in opkomst. ${ }^{3}$ Alternatieve financieringsvormen hebben een vlucht genomen door FinTech. ${ }^{4}$ De Nederlandse regering heeft het stimuleren hiervan opgenomen in het MKB-actieplan. ${ }^{5} \mathrm{Zij}$ vindt het belangrijk dat dit een reëel alternatief is/wordt voor MKB-ondernemingen. ${ }^{6}$ Op Europees niveau is er ook specifiek aandacht voor de mogelijkheid voor ondernemingen om kapitaal op te halen door middel van de uitgifte van effecten. Het is een van de speerpunten van het Capital markets union action plan. ${ }^{7}$

* $\quad$ Dit artikel is geschreven op persoonlijke titel. Wij danken Larissa Silverentand, Bart Bierens en Peter Feijen voor hun waardevolle commentaren op eerdere versies van dit artikel. Mr. J.M. (Jocelyn) Brussen is Senior Legal Counsel bij Rabobank NL. Mr. I.P.M.J. (Ilse) Janssen is Legal Counsel bij Rabobank NL en fellow aan de Radboud Universiteit Nijmegen, Onderzoekcentrum Onderneming \& Recht.

1 Concurrentie op de markt voor MKB-financiering, ACM juni 2015, www.acm.nl, p. 14 (hierna: Rapport ACM 2015).

2 Zie www.kvk.nl/advies-en-informatie/financiering/alternatieve-financieringsvormen/.

3 DNB, Kredietmarkten in beweging, DNB november 2016, p. 5 (hierna: Rapport DNB 2016).

4 FinTech is een aanduiding voor diverse innovatieve technologische ontwikkelingen die in de afgelopen jaren opmars hebben gemaakt binnen de financiële sector. Zie ook A.M.F. Hakvoort, FinTech - een worsteling voor wetgevers en toezichthouders. Brengt het FinTech actieplan verduidelijking?, FR 2018, afl. 6, p. 304.

5 MKB-actieplan, Ministerie van Economische Zaken en Klimaat juni 2018, p. 16 (hierna: MKBactieplan 2018).

$6 \quad$ MKB actieplan 2018, p. 29.

7 Zie https://ec.europa.eu/info/business-economy-euro/growth-and-investment/capital-marketsunion_nl. 
Desalniettemin was in 2016 nog 80\% van de MKB-financiering afkomstig van banken. ${ }^{8}$ Vooral bij 'grote' MKB-ondernemingen is wel een verschuiving naar alternatieve financieringen, zoals de uitgifte van obligaties, zichtbaar. ${ }^{9}$ Maar ook bij 'kleine' MKB-ondernemingen vindt in toenemende mate alternatieve financiering plaats. Zo is crowdfunding ${ }^{10}$ steeds meer een bron van alternatieve financiering voor 'kleine' MKB-ondernemingen. ${ }^{11}$

In dit artikel zullen wij specifiek ingaan op (nieuwe) mogelijkheden voor MKBondernemingen om financiering 'op te halen' door het uitgeven van obligaties via een MTF-platform, via het 'MKB-groeimarktregime' en via een beleggingsonderneming. Ook zullen wij ingaan op de praktische haalbaarheid daarvan voor MKBondernemingen. In het kader van het laatste aspect kijken wij naar (doorlopende) verplichtingen (en naleving), lasten en kosten.

\section{Bancaire financieringen aan het $\mathrm{MKB}$}

Voor de afbakening van het begrip 'MKB-onderneming' sluiten wij aan bij de Europese definitie. Op grond daarvan behoren tot het MKB: alle ondernemingen waarin minder dan 250 personen werkzaam zijn en waarvan de jaaromzet hoogstens $€ 50$ miljoen is of het jaarlijkse balanstotaal de $€ 43$ miljoen niet overschrijdt. ${ }^{12}$ Het overgrote deel van het MKB bestaat overigens uit microbedrijven. ${ }^{13}$

Zoals in de inleiding al kort aan bod kwam, is het merendeel van de MKB-financiering nog steeds afkomstig van banken. ${ }^{14}$ Voordat wij ingaan op de uitgifte van obligaties om financiering aan te trekken, gaan wij hierna eerst kort in op de ban-

8 Rapport DNB 2016, p. 27.

9 Rapport DNB 2016, p. 27.

10 Onder crowdfunding wordt in het algemeen verstaan: het investeren door ter beschikking stellen van geld door een groep investeerders (de 'crowd') aan geldvragers (particulieren of MKB-ondernemingen). Crowdfundingplatformen vervullen een intermediairsfunctie door geldvragers en geldgevers bij elkaar te brengen. Crowdfunding is niet gedefinieerd in de Wft, maar wordt wel door de Wft gereguleerd. Ook zijn Europese regels in de maak (Europese Commissie, COM(2018)113 final, 2018/0048). Voor meer informatie over o.a. crowdfunding zie: Hakvoort 2018, p. 305-312, J. Baukema, Regulering crowdfunding: nationale ontwikkelingen en ontwerp ECSP verordening, FR 2018, afl. 11, p. 517-526, T.F.E. Tjong Tjin Tai, Platformen als uitdaging voor het privaatrecht, WPNR 2018/7214, p. 835-841 en J.M. van Poelgeest, Crowdfunding en compliance, TvC 2017, afl. 2, p. 122-126.

11 Een deel van de hier behandelde (toezichts)regelgeving is ook van toepassing op crowdfunding. De AFM onderscheidt vier vormen van crowdfunding. Zie www.afm.nl/nl-nl/professionals/ onderwerpen/crowdfunding-overig. Zowel bij (1) 'loan based' crowdfunding als bij (2) 'equity based' crowdfunding valt het platform onder de reikwijdte van de Wft. Bij 1 doordat sprake is van bemiddeling en de totstandkoming van leningovereenkomsten, en bij 2 doordat sprake is van het verlenen van beleggingsdiensten.

12 Aanbeveling 2003/361/EG. Deze definitie wordt ook in MiFID II gehanteerd, art. 77 lid 2 Gedelegeerde verordening (EU) 2017/565 (hierna: Gedelegeerde verordening MiFID II).

13 Rapport DNB 2016, p. 27. Men spreekt van microbedrijven als de onderneming minder dan tien werknemers heeft en een jaaromzet van hoogstens $€ 2$ miljoen of een jaarlijks balanstotaal kleiner of gelijk aan $€ 2$ miljoen. Aanbeveling 2003/361/EG.

14 Zie www.nvb.nl/nieuws/4068/banken-nog-steeds-grootste-mkb-financier.html. 
caire financiering. Hieronder verstaan wij zowel leningen als kredieten. Bij een bancaire financiering zijn verschillende looptijden (meestal maximaal vijf of tien jaar) en verschillende soorten rentetypen (bijvoorbeeld vast of variabel) mogelijk. In vergelijking met de uitgifte van obligaties is de bancaire financiering slechts beperkt gereguleerd. ${ }^{15}$

Waarom kan het voor een MKB-onderneming überhaupt interessant zijn om haar financiering door middel van obligaties aan te trekken in plaats van via een bancaire financiering? Een - wellicht voor de hand liggende - reden kan zijn dat niet elke bancaire financieringsaanvraag wordt gehonoreerd. Denk daarbij aan (kleinere) MKB-ondernemingen met relatief weinig eigen vermogen. Of ondernemingen die pas recent zijn opgericht. Zij hebben nog geen 'trackrecord' op basis waarvan de bank haar risico's kan inschatten. ${ }^{16}$

Een andere reden - meer vanuit bancair perspectief - waarom het voor MKBondernemingen lastig kan zijn om een bancaire financiering aan te trekken, is gelegen in de kapitaalseisen die op banken van toepassing zijn. ${ }^{17}$ Kort gezegd moeten banken voor elke lening die zij verstrekken, een minimaal bedrag aan eigen vermogen aanhouden. ${ }^{18}$ Daarnaast moet een bank voor risicovolle financieringen meer eigen vermogen aanhouden dan voor andere leningen. Dat begrenst dus voor banken de financieringen die zij kunnen verstrekken en maakt dat banken ook selectiever zijn in de financieringen die zij verstrekken. ${ }^{19}$

Onder andere door de bovengenoemde ontwikkelingen gaan MKB-ondernemingen soms op zoek naar alternatieve financieringsvormen - in plaats van of naast een bancaire financiering. Dat kan lastig zijn. Er zijn verschillende alternatieve financieringsvormen, maar niet elke vorm past even goed bij de wensen en behoeften van een specifieke onderneming. Bij sommige alternatieve financieringsvormen willen en krijgen geldgevers ook zeggenschap en/of recht op winst. ${ }^{20}$ En dat wil een MKB-onderneming niet altijd. Daarnaast speelt ook mee dat alternatieve financieringen voor een deel van de MKB-ondernemingen nog altijd vrij onbekend zijn. ${ }^{21}$ Verder weten de 'alternatieve' geldgevers de MKB-ondernemingen ook nog niet altijd te vinden. ${ }^{22}$ Zoals we hierna zullen zien, brengen alterna-

15 Sinds 1 juli 2018 is de Gedragscode Kleinzakelijke Financiering in werking getreden. Deze Gedragscode bevat minimumnormen voor het niveau van bescherming en dienstverlening bij bancaire dienstverlening aan kleinzakelijke klanten. Het toepassingsbereik van deze Gedragscode is in beginsel beperkt tot klanten die op groepsniveau 1 een jaaromzet van maximaal $€ 5$ miljoen en op groepsniveau 2 een totale hoofdsom aan bancaire financieringen bij de betreffende financier van maximaal $€ 2$ miljoen hebben op het moment van de financieringsaanvraag.

16 MKB-actieplan 2018, p. 29.

17 De huidige kapitaaleisen voor banken zijn neergelegd in (de regels gebaseerd op) de Richtlijn 2013/36/EU (kapitaalvereisten) en de Verordening (EU) 575/2013 (kapitaalvereisten).

18 Uitvoerig over deze complexe materie: E.P.M. Joosen \& M.K.Z. Groot, Kapitaal- en liquiditeitseisen voor banken (Financieel Juridische Reeks, deel 7), Zutphen: Uitgeverij Paris 2015.

19 Rapport ACM 2015, p. 29.

20 Rapport ACM 2015, p. 29.

21 Rapport ACM 2015, p. 47.

22 MKB actieplan 2018, p. 29. 
tieve financieringsvormen voor MKB-ondernemingen ook andere of meer verplichtingen met zich.

\section{Uitgifte van obligaties en verschillende 'platformen'}

In dit artikel beperken wij ons tot één specifieke alternatieve financieringsvorm voor de MKB-onderneming, namelijk de mogelijkheid om haar financiering/kapitaal op te halen via de uitgifte van effecten in de vorm van obligaties. ${ }^{23}$ De MKBonderneming kwalificeert dan als een 'uitgevende instelling'. ${ }^{24}$

Door de uitgifte van obligaties kan de MKB-onderneming vreemd vermogen aantrekken. Obligaties ${ }^{25}$ zijn leningen van de obligatiehouders aan de uitgevende instelling, waarbij elke obligatiehouder een zelfstandige vordering heeft op de uitgevende instelling. ${ }^{26}$ Een obligatie heeft een van tevoren bepaalde vaste looptijd. Een obligatie geeft recht op rente en aflossing - ineens aan het einde van de looptijd of in delen. ${ }^{27}$ Obligaties komen in een groot aantal vormen voor: kort- of langlopend, al dan niet gesecureerd, al dan niet achtergesteld, al dan niet converteerbaar, vastrentend of met variabele rente. ${ }^{28}$

De uitgifte van effecten is intensief gereguleerd. Aan welke verplichtingen een MKB-onderneming als uitgevende instelling in een specifiek geval precies moet voldoen, is afhankelijk van de wijze waarop zij haar effecten uitgeeft. Er zijn verschillende mogelijkheden, maar wij gaan in dit artikel specifiek in op:

a de uitgifte (en verhandeling) via de multilaterale handelsfaciliteit;

b de MKB-groeimarkt (een species van de multilaterale handelsfaciliteit); en

c de uitgifte via een beleggingsonderneming (zonder handelsplatform).

In een deel van die gevallen is het niet alleen mogelijk om de effecten via het 'platform' uit te geven (primaire markt), maar bestaat er vervolgens ook de mogelijk-

23 Naast obligaties kwalificeren bijvoorbeeld ook aandelen als een effect in de zin van art. 1:1 Wft. Een groot deel van de verplichtingen die wij in dit artikel beschrijven, zijn van overeenkomstige toepassing bij de uitgifte van aandelen. Voorwaarde om als effect te kwalificeren is dat er sprake moet zijn van verhandelbaarheid, art 1:1 Wft. Voor de verhandelbaarheid is vereist dat de eigenschappen van dat instrument verhandeling mogelijk maken. Voorwaarden voor verhandelbaarheid zijn: (1) het instrument is vrij overdraagbaar; (2) het instrument is op enige wijze gestandaardiseerd; en (3) er is een markt voor de verhandeling van de betreffende financiële objecten. Het is niet doorslaggevend of er ook een markt is. De AFM hanteert een ruime economische benadering van het begrip verhandelbaarheid. Beleidsregel verhandelbaarheid, Amsterdam: AFM februari 2011, www.afm.nl.

24 Ieder die effecten heeft uitgegeven of deze wil gaan uitgeven, kwalificeert als uitgevende instelling. Art. 1:1 Wft.

25 Internationaal worden ook vaak de termen 'bonds' en 'notes' gebruikt.

26 Het begrip obligatie is niet gedefinieerd in de wet (BW en Wft). Zie voor meer informatie over obligaties Asser/De Serière 2-IV 2018/160-284.

27 Als er een secundaire markt is, kunnen de obligaties voor de obligatiehouders mogelijk ook rendement opleveren wanneer zij hun obligatie(s) bij een waardestijging kunnen verkopen op de secundaire markt.

Asser/De Serière 2-IV 2018/161. 
heid om deze effecten op dit platform te laten verhandelen (secundaire markt). ${ }^{29}$ Op de secundaire markt kunnen investeerders eerder uitgegeven effecten kopen of verkopen, mits er voldoende vraag en aanbod is.

Hierna komen de specifieke verplichtingen die rusten op een MKB-onderneming bij de uitgifte van obligaties per mogelijkheid aan bod.

\section{Uitgifte en verhandeling op de multilaterale handelsfaciliteit}

Er zijn verschillende soorten handelsplatformen waar obligaties kunnen worden uitgegeven en verhandeld. ${ }^{30}$ Eén daarvan is de multilaterale handelsfaciliteit (hierna: MTF). ${ }^{31}$ De MTF is de laatste jaren in opkomst. Zonder op de details in te gaan is dit kort gezegd een 'lichtere' variant van de gereglementeerde markt ${ }^{32}$ (de 'klassieke' effectenbeurs als handelsplatform, bijvoorbeeld Euronext).

Op dit moment zijn er enkele MTF's actief in Nederland. ${ }^{33}$ NPEX richt zich bijvoorbeeld specifiek op MKB-ondernemingen. En ook Nxchange faciliteert de uitgifte van en handel in obligaties door MKB-ondernemingen.

De MTF biedt niet alleen een platform om obligaties aan te bieden, maar faciliteert daarnaast ook een secundaire markt. ${ }^{34}$ Gezien het feit dat MKB-onderne-

29 Het bestaan van een secundaire markt kan zowel voor de MKB-onderneming als voor investeerder voordelen opleveren. Investeerders kunnen hun effect dan bijvoorbeeld proberen te verkopen als zij hun investering liquide willen maken. Voordeel voor de MKB-onderneming kan zijn dat het voor de investeerder zo aantrekkelijker kan zijn om in deze MKB-onderneming te investeren, omdat de investeerder zijn obligaties op enig moment kan verkopen.

30 Art. 1:1 Wft. Handelsplatform: (a) georganiseerde handelsfaciliteit, (b) gereglementeerde markt of (c) multilaterale handelsfaciliteit.

31 De definitie van MTF in art. 1:1 Wft luidt als volgt: 'door een beleggingsonderneming geëxploiteerd multilateraal systeem dat meerdere koop- en verkoopintenties van derden met betrekking tot financiële instrumenten, binnen dit systeem en volgens de niet-discretionaire regels, samenbrengt op zodanige wijze dat er een overeenkomst uit voortvloeit overeenkomstig de geldende regels inzake de vergunningverlening en het doorlopende toezicht'. Het exploiteren of houden van een MTF is een 'beleggingsactiviteit' in de zin van art. 1:1 Wft. Daarvoor is een vergunning vereist (beleggingsonderneming) op grond van art. 2:96 Wft.

32 Zie voor een uitgebreide vergelijking tussen MTF en gereglementeerde markt A.P.H. Klein \& C.W.M. Lieverse Handelsplatformen onder de MiFID: gereglementeerde markten en multilaterale handelsfaciliteiten, FR 2008, afl. 1/2, p. 23-31.

33 Bloomberg Trading Facility, Tradeweb EU, Nxchange, NPEX en Captin. Zie www.afm.nl/nl-nl/ professionals/registers/vergunningenregisters/handelsplatformen. Register AFM geraadpleegd op 12 februari 2019.

34 Op die secundaire markt kunnen investeerders hun effecten kopen of verkopen, mits er voldoende handel is. Het is gebruikelijk om na de aanbieding van effecten als onderneming 'genoteerd' te blijven aan het platform. Theoretisch bezien kan een onderneming ervoor kiezen om via de MTF enkel haar effecten aan te bieden en vervolgens niet te kiezen voor een notering aan die markt (geen secundaire markt), of direct weer te 'delisten'. Dat is echter niet de gebruikelijke werkwijze. Een mogelijk voordeel voor de onderneming in dat geval is dat de verplichtingen die voortvloeien uit Verordening (EU) 596/2014 (hierna: Marktmisbruikverordening) dan niet van toepassing zijn. Die gelden namelijk enkel als het gaat om financiële instrumenten die worden verhandeld (secundaire markt) op de MTF. Zie art. 2 lid 1 sub b Marktmisbruikverordening. 
mingen zelden of nooit gebruik lijken te maken van de gereglementeerde markt - waarschijnlijk mede gezien de daarmee gepaard gaande (doorlopende) verplichtingen -, komt de gereglementeerde markt in dit artikel enkel aan bod voor zover dat nuttig is in vergelijking met de MTF. Dit vanuit het perspectief van de MKBonderneming die financiering aan wil trekken door middel van de uitgifte van obligaties.

\subsection{Prospectusplicht}

Een belangrijke verplichting die op een uitgevende instelling rust wanneer deze op een MTF 'effecten uitgeeft aan het publiek', is de verplichting om een prospectus op te stellen. ${ }^{35}$ Het prospectus is streng gereguleerd. ${ }^{36} \mathrm{Zo}$ is in de Wet op het financieel toezicht (Wft) vastgelegd dat in dit prospectus alle gegevens moeten worden opgenomen die nodig zijn voor een verantwoord oordeel over onder andere het vermogen, de financiële positie, het resultaat en de vooruitzichten van de uitgevende instelling en een samenvatting van die kerngegevens. ${ }^{37}$ Het doel van het prospectus is om potentiële investeerders inzicht te geven in onder andere de risico's van het effect. ${ }^{38}$ Het prospectus moet vooraf worden goedgekeurd door de AFM. ${ }^{39}$

Onder bepaalde voorwaarden is de uitgevende instelling die haar effecten wil aanbieden 'aan het publiek' op een MTF, echter vrijgesteld van de prospectusplicht. De eerste voorwaarde is dat de effecten die een uitgevende instelling aanbiedt, een totale tegenwaarde vertegenwoordigen van minder dan $€ 5$ miljoen over een periode van twaalf maanden. ${ }^{40,41}$ Deze vrijstelling kan voor MKB-ondernemingen interessant zijn, aangezien veel MKB-ondernemingen niet snel voor meer dan dit bedrag aan effecten zullen uitgeven.

Uitgevende instellingen die gebruik willen maken van deze vrijstelling moeten de uitgifte vooraf melden aan de AFM. Het idee hierachter is de bescherming van beleggers (door deze meldplicht krijgt de AFM een overzicht van de vrijgestelde partijen). Verder moet de uitgevende instelling in plaats van een prospectus

Art. 5:2 Wft. De prospectusplicht is niet alleen van toepassing bij het 'toelaten van effecten op de gereglementeerde markt', maar in principe ook wanneer effecten worden 'aangeboden aan het publiek'.

36 Art. 5:13 t/m 5:19 Wft.

37 Art. 5:13 en 5:14 Wft.

38 Richtlijn 2003/71/EG (Prospectusrichtlijn), overweging 19.

39 Art. 5:2 en 5:6 Wft. De AFM controleert enkel of het prospectus volledig, consistent en begrijpelijk is. De inhoud van het prospectus (of deze juist is) controleert zij niet.

40 Art. 53 lid 2 Vrijstellingsregeling Wft.

41 Tot 1 oktober 2017 was die drempel $€ 2,5$ miljoen. De Prospectusrichtlijn bood lidstaten de ruimte tot een verhoging van de vrijstellingsgrens naar $€ 8$ miljoen, maar in Nederland is - met het oog op beleggersbescherming - gekozen voor een grens van $€ 5$ miljoen als uiterste bedrag, waarbij (volgens de minister) de voordelen van lagere kosten voor uitgevende instellingen nog opwegen tegen het ontbreken van een volledig prospectus voor beleggers. Kamerstukken II 2015/16, 22112, 2051, p. 7 en R.E. Labeur, Een vleugje regulatoire verlichting op de mkb-kapitaalmarkten, FR 2017, afl. 11, p. 531-535. 
gebruik maken van het 'informatiedocument'. ${ }^{42}$ Dit informatiedocument is opgenomen als bijlage in de Vrijstellingsregeling Wft en is een verplicht format. In dit informatiedocument is de uitgevende instelling verplicht om bepaalde informatie op te nemen over onder andere de belangrijkste risico's voor de belegger, het type effect, de kosten voor de belegger, het bestedingsdoel van de inleg, informatie over de uitgevende instelling en haar financiële situatie, het rendement en de aanbieding en inschrijving. ${ }^{43}$ Kortom, het informatiedocument zou de investeerder in staat moeten stellen een afgewogen beleggingsbeslissing te nemen. Je zou het informatiedocument kunnen zien als een (zeer) 'light prospectus'.

Naast de meldplicht en het informatiedocument moet bij het aanbieden van de effecten op alle documenten en reclame-uitingen waarin de aanbieding is opgenomen of in het vooruitzicht wordt gesteld, worden aangegeven dat er geen prospectusplicht geldt en dat de investeerder belegt buiten AFM-toezicht. ${ }^{44}$ Hiervoor heeft de AFM een vrijstellingsvermelding opgesteld: 'Let op! U belegt buiten AFM-toezicht. Geen prospectusplicht voor deze activiteit. ${ }^{\text {'4 }}$

De uitzondering op het gebruik van het prospectus (en in plaats daarvan gebruik maken van het informatiedocument) geldt alleen bij het aanbieden van effecten 'aan het publiek' (zoals bij een MTF) en niet bij het aanbieden en/of verhandelen op een gereglementeerde markt. ${ }^{46}$ Op een gereglementeerde markt is dus altijd een door de AFM goedgekeurd prospectus vereist.

\subsection{Toepassing Marktmisbruikverordening}

Wanneer een MKB-onderneming haar obligaties heeft aangeboden op een MTF en de obligaties vervolgens zijn toegelaten tot de handel op een MTF dan wel daarop worden verhandeld (secundaire markt), zijn ook de verplichtingen uit de Marktmisbruikverordening op haar van toepassing. ${ }^{47}$ Het gaat hierbij om voortdurende verplichtingen voor de MKB-onderneming zolang de obligaties zijn toegelaten dan wel worden verhandeld op de MTF (hoogstwaarschijnlijk gedurende de gehele looptijd van het effect).

Art. 53 lid 4 Vrijstellingsregeling Wft en Bijlage A Vrijstellingsregeling Wft. Als de uitgevende instelling niet tevens de aanbieder is, gelden nog enkele aanvullende verplichtingen op het informatiedocument, art. 53 lid 4 sub a Wft.

43 Bijlage A Vrijstellingsregeling Wft.

44 Art. 53 lid 5 Vrijstellingsregeling Wft.

45 In de praktijk ook wel bekend als het wildwestbordje.

46 De prospectusplicht is van toepassing bij het 'aanbieden van effecten aan het publiek' of 'effecten te doen toelaten tot de handel op een gereglementeerde markt' op grond van art. 5:2 Wft. De uitzondering met betrekking tot het informatiedocument geldt enkel bij het 'aanbieden van effecten aan het publiek' en niet bij het 'doen toelaten tot de handel op een gereglementeerde markt', art. 53 Vrijstellingsregeling Wft. Dit betekent dat een onderneming bij de uitgifte van effecten op een gereglementeerde markt altijd een (door de AFM goedgekeurd) prospectus moet opstellen, terwijl zij bij de uitgifte op een MTF - wanneer sprake is van een aanbieding aan het publiek - gebruik mag maken van het informatiedocument als wordt voldaan aan de voorwaarden.

47 Art. 2 lid 1 sub b Marktmisbruikverordening. Deze verplichtingen zijn ook van toepassing bij andere soorten effecten zoals aandelen. 
Een belangrijke verplichting die voortvloeit uit de Marktmisbruikverordening is de verplichting om voorwetenschap onverwijld openbaar te maken. ${ }^{48}$ Voorwetenschap is kort gezegd informatie die (1) niet openbaar is, (2) voldoende concreet is en rechtstreeks betrekking heeft op de uitgevende instelling en (3) een significante invloed op de koers zou kunnen hebben als zij openbaar wordt gemaakt. ${ }^{49}$ In de Marktmisbruikverordening is ook vastgelegd hoe de uitgevende instelling deze voorwetenschap openbaar moet maken (persbericht aan belangrijke media, nieuwsbureaus en op haar eigen website) en welke informatie zij daarbij precies moet verstrekken. ${ }^{50}$ Slechts onder zeer strikte voorwaarden kan de MKB-onderneming deze openbaarmaking uitstellen. ${ }^{51}$

Zo dient een MKB-onderneming bijvoorbeeld belangrijke feiten over haar financiële positie in principe onverwijld openbaar te maken zoals hiervoor beschreven. Zij mag niet volstaan met enkel een bericht aan haar investeerders, maar moet daadwerkelijk een persbericht opstellen en verspreiden. In het eerste geval zou namelijk slechts een selecte groep op de hoogte raken van die informatie en wordt niet voldaan aan het vereiste van 'openbaren'.

Een ander voorbeeld van een verplichting voor de uitgevende instelling in dit kader is het opstellen van een insiderlijst (dit is een lijst van bij of voor rekening van een uitgevende instelling werkende personen die toegang hebben tot voorwetenschap). ${ }^{52}$ Daarbij valt onderscheid te maken tussen permanente en adhocinsiders. Denk bij permanente insiders aan werknemers en vaste adviseurs en bij incidentele insiders aan personen die voor een specifieke opdracht worden ingeschakeld en ook toegang hebben tot voorwetenschap. Naast het opstellen van deze lijst ${ }^{53}$ moet de uitgevende instelling alle redelijke maatregelen nemen om de insiders schriftelijk te laten verklaren dat zij op de hoogte zijn van de verplichtingen, verboden en sancties die gepaard gaan met het zijn van insider. ${ }^{54}$

Naast bovenstaande vloeien uit de Marktmisbruikverordening bijvoorbeeld ook het tipverbod, het verbod op marktmanipulatie en het verbod op handel met voorwetenschap voort. ${ }^{55}$

De AFM houdt toezicht op de naleving van de verplichtingen die voortvloeien uit de marktmisbruikregels door de uitgevende instelling. ${ }^{56}$ In dit kader kan de AFM sancties opleggen aan de uitgevende instelling. ${ }^{57}$

Art. 17 lid 1 Marktmisbruikverordening.

Art. 7 lid 1 sub a Marktmisbruikverordening.

Art. 14 Marktmisbruikverordening jo. art. 21 Richtlijn 2004/109/EG.

Art. 17 lid 4 Marktmisbruikverordening.

Art. 18 lid 1 Marktmisbruikverordening.

Gezien de relatief zware gevolgen van het zijn van insider lijkt het wenselijk om de lijst van permanente insiders zo beperkt mogelijk te houden en ad-hocinsiders niet ook permanent als insider aan te merken vanuit 'gemak'.

Art. 18 lid 2 Marktmisbruikverordening.

Art. 8 jo. art. 14, 12 jo. art. 15, en 10 Marktmisbruikverordening.

Art. 2 lid 1 sub m Besluit uitvoering EU-verordening financiële markten.

Art. 4 jo. bijlage 1 en art. 5 jo. bijlage 2 Besluit uitvoering EU-verordeningen financiële markten. 


\subsection{Toepassing andere regels}

De MKB-onderneming is verder gehouden aan de Wet oneerlijke handelspraktijken. ${ }^{58}$ Voor de MKB-onderneming die obligaties uitgeeft, is het vooral van belang dat zij zich niet schuldig maakt aan een misleidende handelspraktijk. ${ }^{59}$ Denk bij een misleidende handelspraktijk bijvoorbeeld aan het verstrekken van onjuiste informatie over de belangrijkste kenmerken van het effect. Het is dus van belang om zorgvuldig te zijn met de informatie in het prospectus/informatiedocument. Als sprake is van een oneerlijke handelspraktijk, dan staat de onrechtmatigheid vast en kunnen niet alleen consumentenbeleggers schadevergoeding vorderen, maar kan daarnaast ook de AFM een sanctie opleggen aan de uitgevende instelling. ${ }^{60}$

\subsection{Kosten}

Alle verplichtingen die van toepassing zijn op de MKB-onderneming brengen ook kosten met zich. Zowel aan de uitgifte van de obligaties en de aanbieding op de primaire markt als aan de secundaire markt zijn kosten verbonden. Denk voor de uitgifte van de obligaties bijvoorbeeld aan kosten voor het opstellen van de documentatie: naast het prospectus of het informatiedocument zijn er voor de uitgifte van obligaties ook obligatievoorwaarden nodig. ${ }^{61}$ Daarbij loopt de MKB-onderneming het risico dat zij niet het door haar benodigde bedrag ophaalt doordat onvoldoende investeerders haar obligaties kopen. Toch heeft zij dan kosten moeten maken. Andere kosten voor de MKB-onderneming zijn de toezichtkosten van de $A F M,{ }^{62}$ de kosten voor de aanvraag van een ISIN $^{63}$ en de kosten die betaald moeten worden aan de MTF voor de uitgifte van de obligaties en deelname aan de secundaire markt. Tevens zijn er voor MKB-ondernemingen kosten verbonden aan interne organisatorische maatregelen om de naleving van alle (marktmisbruik)regels te waarborgen en bijvoorbeeld zorgvuldig om te gaan met voorwetenschap en insiders (denk hierbij ook aan de eventuele aanstelling van een compliance officer).

\subsection{Tussenconclusie}

Voor MKB-ondernemingen is het mogelijk om kapitaal op te halen door middel van de uitgifte van obligaties op een MTF. Dat zij daarbij in bepaalde gevallen gebruik mag maken van het informatiedocument in plaats van een prospectus lijkt een positieve ontwikkeling te zijn. Maar daarnaast gelden ook andere ver-

58 Afd. 3A Boek 6 BW. Deze regeling geldt ook bij andere soorten effecten, zoals aandelen.

59 Art. 6:193c BW.

60 Art. 3.4 Wet handhaving consumentenbescherming en art. 6:193b BW.

61 In de obligatievoorwaarden maakt de MKB-onderneming afspraken met haar investeerders over de voorwaarden van de obligatielening. Denk bijvoorbeeld aan het rentepercentage en de opeisingsgronden van de obligatielening.

62 Regeling van de minister van Financiën en de minister van Sociale Zaken en Werkgelegenheid van 31 mei 2018, kenmerk 2018-63331, directie Financiële Markten, tot vaststelling van de bandbreedtes en tarieven, bedoeld in art. 13, negende lid, van de Wet bekostiging financieel toezicht, voor het jaar 2018 (Regeling bekostiging financieel toezicht 2018).

63 International Securities Identification Number. Met deze code kan een verhandelbare financiële waarde wereldwijd uniek worden geïdentificeerd. 
plichtingen die als zwaar en kostbaar kunnen worden ervaren. Zeker voor de kleinere MKB-onderneming, die mogelijk weinig ervaring heeft met de marktmisbruikregels en deze wijze van kapitaal ophalen. Dat lijkt ook te zijn onderkend door de Europese wetgever. Hij introduceerde onlangs de 'MKB-groeimarkt'.

\section{MKB-groeimarktregime}

Sinds de inwerkingtreding van MiFID II op 3 januari 2018 bestaat er ook een variant van de MTF, de MKB-groeimarkt. ${ }^{64}$ De Europese wetgever vond het wenselijk dat MKB-ondernemingen een vlottere toegang tot kapitaal zouden krijgen en dat MTF-markten gericht op het MKB aantrekkelijker zouden worden voor beleggers. Ook vond de wetgever het wenselijk om de administratieve lasten te verlichten. ${ }^{65}$ Om de MKB-groeimarkt aantrekkelijk te maken, voerde de Europese wetgever daarom enkele versoepelingen in ten opzichte van het regime dat op de MTF van toepassing is. Hierbij is gezocht naar een evenwicht tussen een hoog niveau van beleggersbescherming en het verminderen van administratieve lasten voor uitgevende instellingen (het MKB). ${ }^{66}$

Op dit moment wordt er in Nederland nog geen gebruik gemaakt van dit MKBgroeimarktregime. Buiten Nederland zijn wel enkele platformen te vinden die opereren onder het MKB-groeimarktregime. ${ }^{67}$ Vóór de invoering van het MKBgroeimarktregime bestonden er overigens ook al MTF's die zich specifiek richtten op MKB-ondernemingen, maar daarvoor gold het 'gewone' regime van de MTF. ${ }^{68}$

\subsection{Vereisten MKB-groeimarktregime}

Hierna beschrijven wij de wijzigingen van het MKB-groeimarktregime ten opzichte van de MTF en bekijken wij of die wijzigingen inderdaad tot een lastenvermindering voor de MKB-onderneming leiden. $\mathrm{Nu}$ er in Nederland nog geen MTF's zijn die opereren onder het MKB-groeimarktregime, volstaan we hieronder met een analyse van de wet.

Eerst gaan we in op enkele vereisten van het MKB-groeimarktregime:

- Enkel een MTF kan worden aangemerkt als een MKB-groeimarkt. ${ }^{69}$

64 Art. 4:91ea Wft.

65 Richtlijn 2014/65/EU (MiFID II), overweging 132.

66 Richtlijn 2014/65/EU (MiFID II), overweging 133.

67 TV SI DRSP -register ESMA, www.esma.europa.eu/sites/default/files/tv_si_drsp_file.xls. Een voorbeeld is AIM. Geraadpleegd op 12 februari 2019.

68 De verplichtingen die in dat geval op de uitgevende instelling rusten, beschreven wij in par. 4.

69 Art. 4:91ea Wft. Een gereglementeerde markt komt dus niet voor deze kwalificatie in aanmerking. 
- Ten minste $50 \%$ van de uitgevende instellingen aan de MTF moet tot het MKB behoren. Bij obligaties wordt daarbij aansluiting gezocht bij de definitie van MKB zoals besproken in paragraaf $2 .^{70,71}$

De wijzigingen van het MKB-groeimarktregime ten opzichte van de MTF zijn de volgende:

- De uitgevende instelling mag in principe bij de aanbieding van effecten volstaan met een 'toelatingsdocument' in plaats van een prospectus. Het is aan het handelsplatform zelf om regels vast te stellen en toe te passen met betrekking tot de vereisten van dit toelatingsdocument. ${ }^{72}$ In Nederland kennen we op de prospectusplicht al de uitzondering van het informatiedocument bij het 'aanbieden van effecten'. Dit kwam in paragraaf 4.1 aan bod.

- Daarnaast mag de uitgevende instelling op een MKB-groeimarkt voorwetenschap op de website van het handelsplatform publiceren in plaats van op haar eigen website. ${ }^{73}$ Het lijkt erop dat de verplichting om een persbericht uit te vaardigen echter wel gewoon blijft rusten op de uitgevende instelling bij een MKB-groeimarkt. Vanuit die optiek lijkt het dus maar een marginale versoepeling.

- Verder is een uitgevende instelling op een MKB-groeimarkt onder bepaalde voorwaarden niet verplicht om een insiderlijst op te stellen. Deze voorwaarden zijn dat de uitgevende instelling alle redelijke stappen moet nemen om te zorgen dat iedereen die toegang heeft tot voorwetenschap op de hoogte is van de verplichtingen, verboden en sancties die daarmee gepaard gaan. Verder moet zij als de toezichthouder daarom verzoekt, alsnog een lijst van insiders kunnen verstrekken. ${ }^{74,75}$ Ook dit lijkt maar een marginale versoepeling.

70 Art. 77 lid 2 Gedelegeerde verordening MiFID II. Die definitie wordt gebruikt als geen sprake is van een eigenvermogensinstrument. Voor zover het wel gaat om een eigen vermogensinstrument (aandelen) kwalificeert een onderneming als MKB als zij een gemiddelde marktkapitalisatie van $€ 200$ miljoen heeft. Art. 4:91ea lid 2 Wft/art. 77 lid 1 Gedelegeerde verordening MiFID II.

71 Interessant om op te merken is dat op uitgevende instellingen die niet als MKB kwalificeren, maar wel genoteerd zijn aan een MKB-groeimarkt, dezelfde verplichtingen rusten als op de MKBonderneming. Hierdoor ontstaat ongelijkheid. Op een niet-MKB-onderneming die genoteerd is aan een MTF die niet als MKB-groeimarkt wordt gekwalificeerd, rusten zwaardere verplichtingen dan op een niet-MKB-onderneming die genoteerd is aan een MKB-groeimarkt. Deze ongelijkheid ontstaat ook bij MKB-ondernemingen. Toch lijkt dit een bewuste keuze te zijn van de Europese wetgever. Zie COM(2018)331, overweging 4.

72 Tenzij de vereisten vastgesteld in de Prospectusrichtlijn van toepassing zijn. Art. 78 lid 2 sub c-f Gedelegeerde verordening MiFID II.

73 Art. 17 lid 9 Marktmisbruikverordening.

74 Art. 18 lid 6 Marktmisbruikverordening.

75 Dat de Europese wetgever uitgevende instellingen op MKB-groeimarkten heeft vrijgesteld van het opstellen en bijhouden van insiderlijsten, betekent overigens niet dat het platform dat opereert onder het MKB-groeimarktregime de verplichting tot insiderlijsten niet alsnog zou kunnen stellen. Wij denken dat dit in de praktijk wel kan gebeuren. 


\subsection{Wijzigingen na één jaar MKB-groeimarktregime}

Nog geen jaar na de introductie van de MKB-groeimarkt is onlangs een wijzigingsverordening van toepassing geworden die enkele aanvullende 'versoepelingen "76 doorvoert. ${ }^{77}$ We bespreken hierna een aantal van deze wijzigingen. ${ }^{78}$

De eerste wijziging ziet op de insiderlijst. De uitgevende instelling mag haar insiderlijst beperken tot een lijst van permanente insiders en hoeft dus geen lijst aan te leggen met ad-hocinsiders. ${ }^{79}$ Vóór de wijzigingsverordening was een uitgevende instelling aan een MKB-groeimarkt echter vrijgesteld van het opstellen van een lijst van insiders. ${ }^{80}$ De wijziging met betrekking tot de insiderlijst zorgt dus niet voor een verlichting voor de MKB-onderneming, nu zij in de nieuwe situatie toch weer een insiderlijst moet bijhouden.

Een tweede wijziging is dat de uitgevende instelling die de openbaarmaking van voorwetenschap uitstelt (binnen de grenzen van de Marktmisbruikverordening) aan de toezichthouder enkel verantwoording hoeft af te leggen als deze daarom vraagt. Zij hoeft die verantwoording dus niet proactief af te leggen. Dit om de administratieve last voor de MKB-onderneming te beperken zonder daarbij afbreuk te doen aan het toezicht op openbaarmaking van voorwetenschap. ${ }^{81} \mathrm{De}$ verplichting om proactief verantwoording af te leggen aan de toezichthouder gold

76 Ten opzichte van de MTF gold onder het MKB-groeimarktregime overigens ook een 'verzwaring'. Dit omdat uitgevende instellingen verplicht waren tot het publiceren van halfjaarlijkse cijfers, welke verplichting op een MTF in principe nu niet geldt. Met de wijzigingsverordening is dit weer 'gerepareerd'.

77 COM(2018)331. Op de twintigste dag na bekendmaking (25 mei 2018) is de wijzigingsverordening in werking getreden. Zes maanden na de inwerkingtreding is zij ook daadwerkelijk van toepassing geworden. Nederland zet in op een langere implementatietermijn omdat ook het Besluit uitvoering EU-verordening financiële markten moet worden aangepast. Kamerbrieven inzake Informatievoorziening over nieuwe Commissievoorstellen. Fiche 6: Verordening Promotie mkbgroeimarkt (brief van de minister van Buitenlandse Zaken), Kamerstukken II 2017/18, 22112, 2614, p. 8 (Fiche Promotie mkb-groeimarkt).

78 Andere wijzigingen die we niet bespreken, zijn versoepeling regime marktpeilingen, geaccepteerde marktpraktijk ten behoeve van liquiditeitscontracten en melden transacties beleidsbepalers handelen in eigen effecten. $\operatorname{COM}(2018) 331$.

79 Art. 1 lid 4 COM(2018)331.

80 Art. 18 lid 6 Marktmisbruikverordening. Fiche Promotie mkb-groeimarkt, p. 6. Dit laat onverlet dat de MKB-groeimarkt deze verplichting wel op kan leggen aan de uitgevende instelling op haar platform. Als de MKB-groeimarkt echter gunstige 'omstandigheden' voor de MKB-onderneming wil creëren, lijkt dat niet voor de hand te liggen.

$81 \operatorname{COM}(2018) 331$, overweging 8. 
en geldt echter niet in Nederland. ${ }^{82}$ Vanuit Nederlands perspectief is er dus geen sprake van een verlichting, maar verandert er op dit punt niets. ${ }^{83}$

Ten derde wordt de verplichting om halfjaarlijkse cijfers te publiceren - een verplichting die bij de invoering van de MKB-groeimarkt is geïntroduceerd - alweer geschrapt. ${ }^{84}$ Dat laat overigens onverlet dat er sprake moet zijn van passende doorlopende financiële verslaglegging. ${ }^{85}$

\subsection{Tussenconclusie}

Vanuit het perspectief van de MKB-onderneming lijkt ons de impact van de invoering van het MKB-groeimarktregime zeer beperkt. Er gelden weliswaar enkele versoepelingen voor de uitgevende instelling op een MKB-groeimarkt, maar ten opzichte van de regels op een MTF lijkt dit vanuit Nederlands perspectief een relatief kleine versoepeling te zijn. De enige versoepelingen zijn immers dat de MKB-onderneming genoteerd aan een MKB-groeimarkt persberichten niet op haar eigen website hoeft te plaatsen, en dat zij enkel een lijst van permanente insiders hoeft bij te houden in plaats van een insiderlijst met permanente insiders en ad-hocinsiders. Het is maar de vraag hoe materieel deze lastenverlichting is.

Op Europees niveau wordt aangegeven dat de versoepeling die het MKB-groeimarktregime teweegbrengt vooral een positieve impact zal hebben op ondernemingen die al genoteerd zijn aan een MKB-groeimarkt. ${ }^{86}$ En dat deze impact niet heel groot zal zijn. Daarnaast is de verwachting niet dat de versoepeling zal leiden tot een groei in noteringen aan de MKB-groeimarkt. ${ }^{87}$ Gezien de invoering van het MKB-groeimarktregime per 3 januari 2018 en de wijzigingen begin 2019, is het nog te vroeg om daarover uitspraken te doen. De komende jaren zullen moeten uitwijzen of het MKB-groeimarktregime ertoe gaat leiden dat MKB-ondernemingen vaker kapitaal zullen gaan ophalen door de uitgifte van effecten. Gezien de minieme versoepelingen - en op sommige punten zelfs verzwaringen - ligt dit volgens ons niet in de lijn der verwachting.

82 Fiche Promotie mkb-groeimarkt, p. 6. Nederland heeft bij de invoering van de Marktmisbruikverordening gebruik gemaakt van een lidstaatoptie, die erop neerkomt dat een uitgevende instelling in Nederland uitstel pas hoeft te melden op het moment dat zij de voorwetenschap openbaar maakt. De uitgevende instelling mag zich dus beperken tot de melding dát zij uitstel heeft genomen. Slechts op aanvraag van de toezichthouder hoeft zij dat uitstel te verantwoorden. Zie de artikelsgewijze toelichting bij art. III onderdeel C Besluit uitvoering verordening marktmisbruik.

83 De Nederlandse wetgever is kritisch over de wijziging om het uitstel van openbaarmaking van voorwetenschap te melden aan de toezichthouder. Hij geeft aan dat de toezichthouder niets met die informatie kan en daarin het gevaar schuilt dat de toezichthouder het uitstel dan gaat beoordelen, terwijl dat een verantwoordelijkheid van de uitgevende instelling is. Fiche promotie mkbgroeimarkt, p. 6.

84 Zie noot 76.

85 Art. 33 lid 3 sub d MiFID II.

86 SWD/2018/243 final, p. 56.

87 SWD/2018/243 final, p. 53 en 55. 


\section{Uitgifte via beleggingsonderneming (zonder handelsplatform)}

Hiervoor bespraken we enkele mogelijkheden voor de MKB-onderneming om kapitaal door middel van de uitgifte van obligaties op te halen op een handelsplatform. ${ }^{88}$ Het is echter ook mogelijk voor een MKB-onderneming haar obligaties aan te bieden zonder gebruikmaking van een handelsplatform. Zij kan deze aanbieding bijvoorbeeld doen via partijen die websites faciliteren ${ }^{89}$ waarop (MKB-)ondernemingen hun effecten kunnen aanbieden. Het gaat dan om websites/faciliteiten die geen transacties samenbrengen in een zogenaamd 'systeem'. ${ }^{90}$ De MKB-onderneming zoekt via die website 'enkel' haar investeerders voor de primaire uitgifte van de obligaties. Die websites faciliteren ook geen secundaire markt waarop investeerders hun effecten weer over kunnen dragen. ${ }^{91}$

\subsection{Kwalificatie diensten website beleggingsonderneming}

De exploitanten van hiervoor bedoelde websites hebben in beginsel een Wft-vergunning nodig als beleggingsonderneming, omdat de werkzaamheden kwalificeren als beleggingsdienst. ${ }^{92}$ Voordat we ingaan op de verplichtingen voor de MKBonderneming bij deze wijze van uitgifte, is het interessant om te bekijken hoe de diensten van die website nu precies kwalificeren. Als we kijken naar de definitie van het 'verlenen van beleggingsdiensten' in art. 1:1 Wft, dan zouden dat zo op het eerste oog drie diensten kunnen zijn, namelijk: 'het in de uitoefening van een beroep of bedrijf ontvangen en doorgeven van orders van cliënten met betrekking tot financiële instrumenten' (sub a), 'het in de uitoefening van een beroep of bedrijf voor rekening van cliënten uitvoeren van orders' (sub b) en 'het in de uitoefening van beroep of bedrijf plaatsen van financiële instrumenten bij aanbieding ervan als bedoeld in hoofdstuk $5.1 \mathrm{Wft}$, zonder plaatsingsgarantie' (sub f).

Van deze beleggingsdiensten zijn geen wettelijke definities beschikbaar. Ook in de literatuur is hierover nauwelijks geschreven. Met beleggingsdienst sub a wordt bedoeld dat orders van een belegger worden ontvangen en deze vervolgens worden doorgegeven aan een andere beleggingsonderneming, die deze order uitvoert. De beleggingsonderneming die de order doorgeeft, is dan een 'doorgeefluik'. ${ }^{33} \mathrm{Bij}$ beleggingsdienst sub b wordt de order (ook) zelf uitgevoerd door de beleggingsonderneming. Bij sub f fungeert de beleggingsonderneming als schakel tussen de uitgevende instellingen en de beleggers. ${ }^{94}$ Wat precies wordt verstaan onder

Art. 1:1 Wft. Onder handelsplatform wordt verstaan een gereglementeerde markt, MTF en OTF.

Bijv. Duurzaaminvesteren.nl (Crowdinvesting B.V.) en Lendahand.nl (Hands-on B.V.). Deze partijen hebben geen vergunning als gereglementeerde markt of MTF, maar wel voor het verlenen van beleggingsdiensten (art. 2:96 Wft).

Bij een MTF en gereglementeerde markt is dit wel het geval. Zie noot 34.

Wel bieden ze soms een mogelijkheid om de effecten 'terug te kopen'.

De Wft-regels ter zake het verlenen van beleggingsdiensten zijn van toepassing, bijvoorbeeld omdat sprake is van de beleggingsdienst 'ontvangen en doorgeven van orders' in financiële instrumenten, art. 1:1 Wft.

93 L. Silverentand \& F. van der Eerden (red.), Hoofdlijnen Wft, Deventer: Wolters Kluwer 2018, p. 191.

Silverentand \& Van der Eerden 2018, p. 191-192. 
'plaatsen' is ons echter niet duidelijk. Ook het onderscheid tussen 'plaatsen' en 'ontvangst en doorgifte van orders' is niet uitgewerkt in de regelgeving of in de literatuur.

Wij vragen ons in het licht van bovenstaande dan ook af hoe de werkzaamheden van een website zoals hierboven bedoeld - waarbij deze fungeert als tussenschakel tussen uitgevende instellingen en beleggers - precies kwalificeren. Daarbij zal het ook aankomen op interpretatie en vormgeving van de website en de activiteiten van het platform: doet een beleggingsonderneming 'iets' in de ondersteuning bij het plaatsen van de obligaties, dan zou je kunnen zeggen dat deze probeert effecten bij beleggers te plaatsen, en sprake is van 'plaatsingsdiensten'. Maar onder 'ontvangst en doorgifte van orders' valt ook het samenbrengen van beleggers. ${ }^{95}$ Bij ontvangst en doorgifte van orders denken wij zelf aan een meer passieve rol, die beperkt is tot het ontvangen en doorgeven van de opdracht, terwijl wij bij plaatsingsdiensten meer zouden denken aan een 'plaatsingsagent' die probeert als tussenpersoon effecten bij beleggers te plaatsen door 'op zoek' te gaan naar beleggers. ${ }^{96}$

Nadat de uitgifte van effecten via een beleggingsonderneming heeft plaatsgevonden, zijn er - ten opzichte van de eerder besproken mogelijkheden - wel minder waarborgen in het kader van beleggersbescherming. Dit aangezien ná het uitgeven van effecten minder doorlopende verplichtingen op de uitgevende instelling rusten. Wij zullen dit hierna bespreken.

\subsection{Verplichtingen MKB-onderneming}

Uit de voorgaande paragrafen bleek dat met de aanbieding van obligaties en vervolgens de notering aan een MTF of MKB-groeimarkt voor de MKB-onderneming een fors aantal verplichtingen gemoeid is, die wellicht specifiek door MKB-ondernemingen als zwaar ervaren kunnen worden. De vraag is of deze verplichtingen voor de MKB-onderneming minder zwaar zijn wanneer zij haar obligaties aanbiedt via een website zoals hiervoor beschreven. Wij zullen dit hierna verder uitwerken.

\subsubsection{Prospectusplicht}

Allereerst de prospectusplicht. Ook wanneer de obligaties worden aangeboden via een website, geldt de prospectusplicht. Deze plicht geldt immers ook (al) bij het aanbieden van effecten 'aan het publiek' ${ }^{97}$ En dat is wat er gebeurt als de MKBonderneming haar obligaties uitgeeft via een website van een beleggingsonderneming zoals hiervoor beschreven. De MKB-onderneming kan in dat geval wel - net

95 Op grond van MiFID II valt het in contact brengen van twee beleggers, zodat er tussen hen een belegging tot stand kan komen, onder het 'ontvangen en doorgeven van orders'. Zie overweging 44 MiFID II.

96 Overigens is bij een plaatsingsdienst de uitgevende instelling de cliënt - en bij 'ontvangen en doorgeven van orders' de belegger de cliënt. Daardoor kunnen deze twee diensten samenlopen. Dit laten wij verder buiten beschouwing omdat onze focus in dit artikel ligt op de uitgevende instelling.

97 Art. 5:2 sub a Wft. 
als op de MTF - gebruik maken van de Vrijstellingsregeling Wft. Dat leidt ertoe dat de MKB-onderneming mag volstaan met het informatiedocument in plaats van een prospectus, mits zij voldoet aan de gestelde voorwaarden. Zie verder hierboven in paragraaf $4.1 .{ }^{98}$

\subsubsection{Marktmisbruikregels}

Dan de marktmisbruikregels. Deze zijn niet van toepassing wanneer de obligaties worden aangeboden via een beleggingsonderneming die enkel een website faciliteert waar uitgevende instellingen hun obligaties primair kunnen aanbieden, zonder daarbij een secundaire markt te faciliteren. ${ }^{99} \mathrm{Nu}$ er geen sprake is van een notering en verhandeling op een handelsplatform, zijn er ook geen doorlopende verplichtingen uit hoofde van de Marktmisbruikverordening van toepassing op de MKB-onderneming.

\subsubsection{Kosten}

Uit het voorgaande vloeit voort dat de MKB-onderneming in deze situatie ook minder kosten zal hoeven te maken. Zij hoeft bijvoorbeeld in principe geen toezichtkosten aan de AFM te betalen, ${ }^{100}$ en er zijn ook geen kosten voor een notering aan de secundaire markt (nu die ontbreekt). Verder zal ook het feit dat de verplichtingen uit de Marktmisbruikverordening niet van toepassing zijn, de MKB-onderneming kosten besparen. Zij hoeft bijvoorbeeld geen persberichten uit te geven.

\subsubsection{Tussenconclusie}

Door haar obligaties uit te geven via een beleggingsonderneming die geen handelsplatform faciliteert, is de MKB-onderneming onder andere niet gehouden aan de regels uit de Marktmisbruikverordening. Dat levert een lastenverlichting op voor de MKB-onderneming ten opzichte van de uitgifte via de MTF of de MKBgroeimarkt. Een mogelijk nadeel voor de MKB-onderneming is wel dat er wellicht minder beleggers geïnteresseerd zijn in haar obligaties. Er wordt namelijk geen secundaire markt gefaciliteerd waarop de belegger zijn obligaties kan overdragen. ${ }^{101}$ Concreet betekent dit dat een belegger zelf op zoek zal moeten naar een

98 In het kader van de beleggersbescherming is de aanbieder wel verplicht om op zijn website de vrijstellingsvermelding ('Let op! U belegt buiten AFM-toezicht. Geen prospectusplicht voor deze activiteit') te publiceren. Art. 2:1 lid 2 Nadere regeling gedragstoezicht financiële ondernemingen.

99 De regels van marktmisbruik zijn dan niet van toepassing, aangezien er geen sprake is van financiële instrumenten die - kort gezegd - zijn toegelaten (genoteerd) of worden verhandeld op een gereglementeerde markt of een MTF. Art. 2 lid 1 Marktmisbruikverordening.

100 Mits er geen sprake is van een door de AFM goedgekeurd prospectus. Zie voor de situatie waarin de uitgevende instelling gebruik kan maken van het informatiedocument in plaats van een door de AFM goedgekeurd prospectus, par. 4.1.

101 Daarnaast zijn bij deze mogelijkheid om obligaties uit te geven zonder handelsplatform minder regels van toepassing. Dit heeft onder andere invloed op de beleggersbescherming. Het kan leiden tot meer oneigenlijk gebruik. Denk bijvoorbeeld aan minder transparantie over de prijs en de handel. 
andere belegger als hij zijn effect over wil dragen. Het is in dat geval voorstelbaar dat hij deze niet vindt en dus aan het effect 'vastzit'.

\section{Conclusie}

In dit artikel hebben wij de mogelijkheden voor MKB-ondernemingen onderzocht voor het aantrekken van kapitaal door de uitgifte van obligaties en de haalbaarheid daarvan voor hen. Wij hebben ons daarbij gericht op de uitgifte van obligaties via een MTF, een MKB-groeimarkt en via een beleggingsonderneming.

Als gevolg van de strenge regulering rusten daarbij op de uitgevende instelling veel verplichtingen. Die verplichtingen zouden voor MKB-ondernemingen een drempel kunnen opwerpen om gebruik te maken van deze mogelijkheid van aantrekken van kapitaal. De naleving van deze verplichtingen brengt kosten met zich voor de MKB-onderneming.

Daarbij zien we wel dat de wetgever hierop heeft ingespeeld door de invoering van het MKB-groeimarktregime als alternatief voor de MTF. Dit heeft weliswaar geleid tot een aantal wijzigingen, maar slechts enkele daarvan zijn versoepelingen voor de MKB-onderneming. Verder is het de vraag in hoeverre deze versoepelingen zullen worden ervaren als een daadwerkelijke lastenverlichting.

Een derde alternatief voor de MKB-onderneming is de uitgifte van obligaties via een beleggingsonderneming die geen handelsplatform faciliteert. In dat geval is er geen secundaire markt en is de MKB-onderneming niet gehouden aan de regels uit de Marktmisbruikverordening. Dat lijkt een lastenverlichting op te leveren voor de MKB-onderneming ten opzichte van de uitgifte via de MTF of de MKBgroeimarkt. Gezien het ontbreken van een secundaire markt zouden echter minder beleggers geïnteresseerd kunnen zijn in de obligaties van de MKB-onderneming.

Er zijn zeker mogelijkheden voor de MKB-onderneming om haar kapitaal op te halen door middel van de uitgifte van obligaties, maar dan moet zij wel bereid zijn de bijbehorende verplichtingen te aanvaarden en na te leven. 